\title{
Encyclopedia of Politics of the American West
}

\section{Agriculture, U.S. Department of}

Contributors: Steven L. Danver

Print Pub. Date: 2013

Online Pub. Date: May 21, 2013

Print ISBN: 9781608719099

Online ISBN: 9781452276076

DOI: $10.4135 / 9781452276076$

Print pages: $160-161$

This PDF has been generated from SAGE knowledge. Please note that the pagination of the online version will vary from the pagination of the print book. 


\subsection{5/9781452276076.n36}

The U.S. Department of Agriculture (USDA) was established in 1862 (Pub. L. 37-62) to provide governmental direction to this critically important economic sector. Other significant national agricultural legislation includes the 1862 Morrill Act (Pub. L. 37130), which established a system of land-grant universities emphasizing agricultural education; the 1887 Hatch Act (Pub. L. 49-297), which established experiment stations to promote agricultural research at these universities; the 1890 Morrill Act (Pub. L. 51249), which incorporated historically black southern universities into the land-grant system; and the 1914 Smith-Lever Act (Pub. L. 63-95), which set up federal- and statefunded extension centers to disseminate scientific agricultural research to farmers.

Governmental involvement in agriculture became more pronounced during the New Deal era through the passage of legislation such as the 1938 Agricultural Adjustment Act (Pub. L. 75-340), which established price supports for various agricultural commodities, including butter, raisins, sorghum, and wool. Subsequent decades saw USDA provide additional price supports for commodities grown in the West and other U.S. regions; regulate crop production; assist farmers with crop insurance to protect them from natural disasters, including drought and flood; and promote irrigation projects to bring water to western regions that typically experience low annual rainfall and frequent climactic volatility.

The USDA seeks to influence western agricultural trends and developments. For example, it addresses the controversial issue of genetically modified organisms in animals and plants. It is also concerned with agricultural marketing; expanding broadband computer network access and economic development opportunities; cattle, poultry, dairy, fruit, vegetable, and wine production; climate change and renewable energy; food safety, irrigation and water management; and soil conservation. It also regulates organic agriculture and promotes farmers' markets, locally produced agriculture, and U.S. agricultural product exports. Relations between USDA and western farmers and ranchers have been either cooperative or contentious, depending on economic circumstances and the agricultural policymaking objectives of presidential administrations. Agriculture, U.S. Department of 
The West's growing population in recent decades has resulted in both increased agricultural production and political influence, as reflected by westerners from both political parties serving as secretary of agriculture. These include Idaho's Ezra Taft Benson during the Eisenhower administration, California's Richard Lyng during President Reagan's second term, Kansas's Dan Glickman during the Clinton administration, and California's Ann Veneman during George W. Bush's first term. Western political influence is also reflected in congressional agriculture oversight committee membership during the 112th Congress, with senators representing Montana, Nebraska, Colorado, and both Dakotas serving on this committee and House members representing California, Colorado, and Oregon.

The rich variety of agricultural activity promoted by USDA is reflected in the multiplicity of western U.S. agricultural production. California had 81,500 farms in 2009; Wyoming farms averaged 2,745 acres during that same year. Washington's Fourth Congressional District was the leading producer of fruits, tree nuts, and berries in 2007 with sales of $\$ 1,640,710,000$, with the next six biggest producers in this area being California congressional districts. Texas's Fifteenth and Twenty-Eighth congressional districts had the most Hispanic agricultural operators, according to the 2007 Census of Agriculture. Also in 2007, the top ten congressional districts in potato, sweet potato, other vegetable, and melon sales from this census were in western states, led by California's Seventeenth Congressional District with $\$ 1,488,609,000$ in sales.

Numerous issues confront western agriculture and governmental agricultural policymaking. These include possible declines in federal price support and governmental budget cuts for agricultural programs as a result of significant overall [p. $160 \downarrow$ ] spending reductions in response to federal budget deficits. These pressures were particularly reflected in the recommendations from the Joint Congressional Committee on Deficit Reduction (popularly known as the Simpson-Bowles Commission) appointed in 2011 and in the debates over the 2012 quinquennial farm bill.

The contentiousness of illegal immigration will also confront USDA policymaking and western politics. Much U.S. agricultural production depends heavily on a workforce of undocumented immigrants. Governmental attempts to clamp down on this activity through stringent implementation of the Department of Homeland Security's E-Verify program, which requires employers to employ only individuals legally authorized to work 
in the United States, is likely to meet with resistance from many western agricultural producers. It may also have a negative impact on U.S. agricultural production and drastically increase consumer food prices. USDA will continue to play a critical role in shaping western and national agricultural and environmental policy and economic development.

Albert T. Chapman

10.4135/9781452276076.n36

See also

\section{Further Readings}

Harding, Thomas Swann. Two Blades of Grass: A History of Scientific Development in the U.S. Department of Agriculture . New York: Arno Press, 1980.

U.S. Department of Agriculture . National Agricultural Statistics Service. Agricultural Statistics of the United States . Washington, DC: U.S. Department of Agriculture, 2010.

U.S. Department of Agriculture . National Agricultural Statistics Service. Census of Agriculture, 2007 . Washington, DC: U.S. Department of Agriculture, 2007-2010. 